\title{
Chronic Chloroquine and Ethanol Administration Causes Detrimental Renal Morphological Changes in Rats Fed Low Protein
}

\author{
Abdurrahman Abdulkadiri,2, Ejikeme Felix Mbajiorgu ${ }^{1}$ \\ ${ }^{1}$ Division of Histology and Embryology, School of Anatomical Sciences, Faculty of Health Sciences, \\ University of the Witwatersrand, Johannesburg, Gauteng, South Africa \\ 2Department of Anatomy, College of Health Sciences, Federal University Birnin Kebbi, PMB 1157, Kebbi State, Nigeria
}

\author{
SUMMARY
}

The aim of the study was to investigate the microscopic renal changes resulting from the concurrent administration of chloroquine and ethanol, with inadequate dietary protein using rats.

Sixty-four rats were randomly distributed into eight groups of eight rats each: control groups on normal protein (NPC) or low protein diet (LPC); chloroquine treatment groups on normal protein (NPQ) or low protein diet (LPQ); ethanol treatment groups on normal protein (NPE) or low protein diet (LPE); concurrent chloroquine and ethanol treatment groups on normal protein (NPQE) or low protein diet (LPQE). Chloroquine in $\mathbf{0 . 9 \%}$ normal saline was administered weekly to NPQ, LPQ, NPQE, and LPQE. While NPE, LPE, NPQE and LPQE received $6 \%$ ethanol in drinking water ad libitum, NPC and LPC received $0.9 \%$ normal saline and plain drinking water. After treatment, routine haematoxylin and eosin stain, Masson's trichrome stain for collagen, kidney volume estimation, glomeruli count, immunofluorescence for aquaporin 2 and urine volume estimation were conducted.

The results showed a decreased kidney volume in all the experimental groups compared to the control. There was increased collagen fibre deposition and distortion of renal histology in the experimental groups compared to control.

Concurrent administration of chloroquine and alcohol causes distortion of kidney histology and derangements of renal function in the low protein fed rats and can cause kidney failure.

Key words: chloroquine, ethanol, low protein, VGStudio, aquaporin 2

Corresponding author:

Abdurrahman Abdulkadir

e-mail: a.abdulkaadir@fubk.edu.ng 


\section{INTRODUCTION}

Chloroquine was first synthesized in 1934 for the treatment and prophylaxis of malaria (1). Chloroquine is also useful in treating rheumatoid arthritis and systemic lupus erythematosus (2). These require a long duration of administration and can lead to cumulative toxicity in the body.

Chloroquine use is sometimes associated with concurrent alcohol consumption in most African countries (3), where malaria is endemic. People consume alcohol while on chloroquine treatment for malaria or rheumatoid arthritis, ignorant of the lethal toxicity of the combination. Musabayane et al. (4) reported derangement of renal function resulting from concurrent administration of chloroquine and ethanol. However, due to the lack of histological and morphometric data, there is a need to study and document the renal histological and morphometric from the chloroquine-alcohol interaction, emphasizing sub-Saharan Africa, where poverty helped malaria prevalence. Furthermore, proper and adequate nutrition is always a challenge in sub-Saharan Africa.

Protein malnutrition is one of the most familiar nutritional problems in Africa due to poverty. Histological changes associated with protein malnutrition had been reported and might lead to organ failure (5). Knowledge of the toxicity of chloroquine and ethanol concurrent administration in protein malnourished condition is vital in these communities, mostly because of the reports of an increase in chronic kidney disease worldwide and sub-Saharan Africa (6).

Adequate dietary protein intake helps mitigate expected renal histological changes (7). Hence, this study investigated the effects of combined administration of chloroquine and alcohol on renal morphology with inadequate dietary protein intake to mimic the situation in sub-Saharan Africa where inadequate nutrition and malaria complicate chloroquine and alcohol abuse.

\section{MATERIALS AND METHOD}

\section{Ethics, animals and housing}

The Animal Ethics Screening Committee of the University of the Witwatersrand (Ethics clearance number: AESC 2015/11/54C) approved this study. Sixty-four adult male Sprague Dawley rats were used. The sample size was calculated based on the resource equation method $(\mathrm{E}=$ Total number of animals - Total number of groups). The rats were individually housed in Perspex cages lined with sawdust and paper shreds with the temperature maintained at $21 \pm 1^{\circ} \mathrm{C}$ and a 12-hour light cycle; feed was supplied ad libitum to all the rats. The rats were allowed one week to acclimatize to the cages before the experiment commenced.

\section{Chloroquine, ethanol and low protein diet preparations}

Chloroquine phosphate salt (Sigma-Aldrich, PHR1258) was reconstituted in our laboratory with $0.9 \%$ saline to make $10 \mathrm{mg} / \mathrm{ml}$ solution, the safe dose used in malaria treatment and research (8). Alcohol stock solution of $100 \%$ ethanol was diluted to make $6 \%$ ethanol in drinking water $\mathrm{v} / \mathrm{v}$. This alcohol concentration approximates the alcohol content in beer, which is the most typical alcoholic beverage in the world (9). A low protein diet (6\% protein) was reconstituted from the standard rat diet (23\% protein) (Nutrition hub, South Africa). Table 1 shows the proximate analyses of the feeds.

Table 1. Proximate feed analyses

\begin{tabular}{l|c|c|c}
\hline \hline Components & Unit & $\begin{array}{c}\text { Control } \\
\text { diet } \\
(23 \% \text { of } \\
\text { protein) }\end{array}$ & $\begin{array}{c}\text { Low } \\
\text { protein } \\
\text { diet } \\
(6 \% \text { of } \\
\text { protein) }\end{array}$ \\
\hline Dry matter & $\%$ & 91.11 & 92.78 \\
\hline Moisture & $\%$ & 8.89 & 7.22 \\
\hline Ash & $\%$ & 6.99 & 3.35 \\
\hline $\begin{array}{l}\text { Fat } \\
\text { (ether extraction) }\end{array}$ & $\%$ & 3.34 & 3.25 \\
\hline Crude fibre & $\%$ & 2.60 & 3.74 \\
\hline Protein $(\mathrm{N} \times 6.25)$ & $\%$ & 22.75 & 5.73 \\
\hline Calcium & $\%$ & 1.32 & 2.95 \\
\hline Phosphorous & $\%$ & 0.62 & 0.15 \\
\hline Total energy & $\mathrm{MJ} / \mathrm{kg}$ & 16.58 & 15.97 \\
\hline \hline
\end{tabular}

\section{Study design}

Sixty-four adult (9 weeks old, average weight $405 \pm 24 \mathrm{~g}$ ) male rats were weighed and randomly assigned into two groups of 32 rats each (normal and low protein groups: NP and LP respectively) based 
on the dietary protein content. Each dietary group comprised four randomly assigned subgroups of eight rats: control groups on normal protein (NPC) or low protein diet (LPC); chloroquine treatment groups on normal protein (NPQ) or low protein diet (LPQ); ethanol treatment groups on normal protein (NPE) or low protein diet (LPE); concurrent chloroquine and ethanol treatment groups on normal protein (NPQE) or low protein diet (LPQE). All rats in the LP group fed on low protein diet one week before the experiment to acclimatise.

Chloroquine was administered by intraperitoneal injections weekly at $0.1 \mathrm{ml} / 100 \mathrm{~g}$ (equivalent of $1 \mathrm{mg} / 100 \mathrm{~g}$ dose) body weight to the subgroups NPQ, LPQ, NPQE and LPQE. In contrast, subgroups NPC, NPE, LPC and LPE received $0.1 \mathrm{ml} / 100 \mathrm{~g}$ of $0.9 \%$ intraperitoneal saline injections weekly for the 60 days duration of the experiment. Ethanol was supplied in drinking water at $6 \% \mathrm{v} / \mathrm{v}$ ad libitum to the subgroups NPE, LPE, NPQE and LPQE, whereas subgroups NPC, NPQ, LPC and LPQ received plain drinking water ad libitum.

To estimate the 24-hour urine volume, the rats were placed individually in a metabolic cage for a 24-hour duration on days 0,30 and 60 of the experiment to monitor urine output. After 24 hours in the cage, collected urine volume is then measured using a calibrated measuring cylinder.

\section{Termination of the experiment}

After 60 days, animals' weight was measured using calibrated Snowrex electronic scale (Clover scales, South Africa) and they were euthanized with an overdose of sodium pentobarbitone (Euthanaze ${ }^{\circledR}$ ) $20 \mathrm{mg} / 100 \mathrm{~g}$ body weight intraperitoneal injection. Kidneys were immediately removed through a midline abdominal incision and immersed in 10\% neutral buffered formalin for fixation. Kidney wet weight was measured at termination using calibrated RADWAG sensitive electronic scale (Wagi Elektroniczne, Poland) before fixation, and the relative organ weight was derived using body weight percentage.

\section{Three-dimensional volume rendering using}

\section{VGStudio}

The formalin-fixed kidney was scanned with a Nikon X TH 225/320 microfocus computed tomography machine (Nikon, UK). The scanned images were reconstructed to a three-dimensional file and imported into VGStudio Max software version 3.0 (Volume Graphics GmbH, Germany) for analysis. The surface determination option was then used to separate the kidney tissue from the background. The region growing option was then used to demarcate and select only the kidney tissue for 3D volume analysis. The volume analyser option was executed to get the result of the volume analysis.

\section{H\&E staining}

Formalin-fixed kidney tissues were routinely processed for histological analyses; five $\mu \mathrm{m}$ sections were cut using a rotary microtome (Jung Biocut 2035, Leica, Germany) and taken on gelatin-coated slides, dewaxed, hydrated through graded alcohol series and then stained as follows: Mayer's Hematoxylin for 5 minutes, washed in running water for 5 minutes, two dips in $1 \%$ acid alcohol to differentiate slide. Then, they were washed in running water for 5 minutes and counterstained in Eosin for 30 seconds. They were washed briefly in running water, dehydrated in series of alcohol, cleared in xylene, mounted with Entellen ${ }^{\circledR}$ and coverslipped.

Photomicrographs of the H\&E stained sections were taken with Axiocam HRc2 camera attached to the Axioskop 2 microscope (Zeiss, Germany) for histopathological evaluation and glomeruli counting.

\section{Glomeruli counting method}

On the H\&E stained sections, random nonoverlapping fields in the renal cortex were photographed using Axiocam HRc2 camera attached to Axioskop 2 microscope (Zeiss, Germany $\mathrm{GmbH}$ ) and imported into ImageJ. A grid was superimposed, and the glomeruli within the field were counted, while any of the glomeruli cut by the field edge were not counted. In each $(n=5)$ of the experimental group and control, ten fields were examined, and a mean was taken. The result of the counting is the number of glomeruli in a single camera field at $10 \mathrm{x}$ magnification $\left(5.78 \mathrm{~mm}^{2}\right.$ area $)$

\section{Masson's trichrome staining}

The $5 \mu \mathrm{m}$ sections taken on gelatin-coated slides were dewaxed and hydrated through graded alcohol series and then stained as follows: celestine 
blue for 5 minutes, then Mayer's Hematoxylin for 5 minutes, then three dips in $1 \%$ acid alcohol, then acid fuchsin for 5 minutes, then phosphomolybdic acid for 5 minutes, then light green for 5 minutes, then $1 \%$ acetic acid for 2 minutes. Then, the sections were dehydrated through graded alcohol and cleared in xylene, mounted with Entellen ${ }^{\circledR}$, and coverslipped.

Photomicrographs of the Masson's trichromestained sections were taken with Axiocam HRc2 camera attached to Axioskop 2 microscope (Zeiss, Germany) for collagen fibre evaluation. Furthermore, a grid was overlaid on random non-overlapping fields on the microphotographs using ImageJ. The area fraction of the collagen fibre was calculated as the collagen deposition area per singlecamera field at $\times 10$ magnification $\left(5.78 \mathrm{~mm}^{2}\right.$ area) in ten fields, and the average was taken $(n=5)$. Points of grid intersection on the collagen deposition were counted, and then the points were multiplied by area per point $\left(0.07 \mathrm{~mm}^{2}\right)$ to get the collagen deposition area. The area fraction of the collagen fibres is defined as the collagen deposition area divided by $5.78 \mathrm{~mm}^{2}$.

\section{Aquaporin 2 water channel immunofluorescence}

Five $\mu \mathrm{m}$ tissue sections were taken on silanecoated slides, dewaxed, hydrated, and then washed in tap water for immunofluorescence procedure. Heat antigen retrieval was done in a microwave oven at 720-watt power for ten minutes, using citrate buffer at $\mathrm{pH}$ 6.0. Then, the sections were washed in phosphate-buffered saline (PBS) and then incubated with $10 \%$ normal goat serum in PBS to block antigen for one hour. Sections were then incubated with rabbit anti-aquaporin 2 (Abcam, ab15116, 1:500 dilution) primary antibody in PBS overnight at $4^{\circ} \mathrm{C}$.

On the second day, sections were washed in PBS and incubated with goat anti-rabbit Alexa flour 488 (Abcam, ab150077) secondary antibody in PBS for 1 hour in the dark at room temperature. Then, they were washed with PBS and incubated with 4', 6diamidino-2-phenylindole, dihydrochloride (DAPI) nuclear stain for 5 minutes and then washed, coverslipped with fluoromount ${ }^{\circledR}$, allowed to dry and kept at $4^{\circ} \mathrm{C}$ until viewing and analysis.

Fluorescence images were captured using the XC10 digital camera attached to the Olympus IX51 inverted fluorescence microscope (Olympus, Japan).
Images of Alexa fluor channel were acquired at 300 ms exposure time, while images of DAPI channel were acquired at $70 \mathrm{~ms}$ exposure time. CellSens dimension 1.11 image analysis software was used to overlay the Alexa fluor channel and DAPI channel. Alexa Fluor channel represents the aquaporin 2 expression, while DAPI channel represents nuclear expression.

\section{Statistical analysis}

Data management, visualization and statistical analysis were conducted with GraphPad prism 9.0. Differences of $\mathrm{p}<0.05$ were considered significant. Tabular data and bar graphs are presented as the mean and standard deviation (SD).

Normality was tested with the Shapiro-wilk test, one-way analysis of variance (ANOVA) and the Kruskal-Wallis test was used for parametric data and non-parametric data, respectively. Tukey post-hoc was used for multiple mean pairwise comparisons in significant one-way ANOVA and Dunn multiple comparisons for significant Kruskal-Wallis test. Repeated measures two-way analysis of variance (ANOVA) was used to analyze body weight and urine volume parameters. Mean pairwise comparison was conducted between baseline and aftertreatment parameters as well as between the animal groups.

\section{RESULTS}

\section{Body weight}

All rats were in good health before the experiment, and at termination, no mortality or signs of any behavior change were recorded. Body weight at termination was significantly lower in the entire LP group than NPC compared to their cohorts in NP (two-way repeated-measures ANOVA, p $<0.0001$, $\mathrm{DF}=7, \mathrm{~F}=91.86)$. Additionally, comparing initial body weight to the terminal body weight shows a significant weight gain in the NP group (Two-way repeated-measures ANOVA, $\mathrm{p}<0.0001, \mathrm{DF}=7, \mathrm{~F}=$ 91.86). However, the LP group did not gain weight throughout the study. The percentage body weight gain of rats in NPC, NPQ, NPE and NPQE were $42.43 \%, 37.31 \%, 36.63 \%$ and $33.09 \%$ respectively, whereas the percentage weight loss in LP-treated rats, LPC, LPQ, LPE and LPQE was 0.53\%, 1.56\%, $1.13 \%$ and $4.08 \%$ respectively (Table 2 ). 
Table 2. Changes in body weight $(g)$ of the control and experimental groups

\begin{tabular}{|c|c|c|c|c|c|c|c|c|}
\hline & NPC & NPQ & NPE & NPQE & LPC & LPQ & LPE & LPQE \\
\hline $\begin{array}{l}\text { Initial body } \\
\text { weight }(\mathrm{g})\end{array}$ & $\begin{array}{l}392 \pm \\
32\end{array}$ & $\begin{array}{l}422 \quad \pm \\
46\end{array}$ & $\begin{array}{l}439 \pm \\
69\end{array}$ & $\begin{array}{l}427 \quad \pm \\
41\end{array}$ & $434 \pm 35$ & $440 \pm 49$ & $423 \pm 35$ & $440 \pm 56$ \\
\hline $\begin{array}{l}\text { Terminal body } \\
\text { weight }(\mathrm{g})\end{array}$ & $\begin{array}{ll}557 \quad \pm \\
39 & \\
\end{array}$ & $\begin{array}{ll}575 & \pm \\
30 & \\
\end{array}$ & $\begin{array}{ll}594 \quad \pm \\
64\end{array}$ & $\begin{array}{ll}565 & \pm \\
42 & \\
\end{array}$ & $\begin{array}{ll}431 & \pm \\
29^{*} & \\
\end{array}$ & $434 \pm 56^{* *}$ & $418 \pm 38^{* *}$ & $422 \pm 60^{* *}$ \\
\hline $\begin{array}{l}\text { Weight } \\
\text { gain/loss (g) }\end{array}$ & $\begin{array}{ll}165 & \pm \\
29 & \\
\end{array}$ & $\begin{array}{ll}153 & \pm \\
33 & \\
\end{array}$ & $\begin{array}{ll}156 & \pm \\
31 & \\
\end{array}$ & $\begin{array}{ll}138 & \pm \\
32 & \\
\end{array}$ & $-3 \pm 16$ & $-6 \pm 14$ & $-5 \pm 16$ & $-18 \pm 29$ \\
\hline
\end{tabular}

Asterisks * indicate significant difference $(P<0.01)$ compared to control (NPC) while ** indicate significant difference $(p<0.01)$ compared to NPC and respective cohorts (i.e. NP vs LP dietary groups). Pilcrow indicates significant difference in weight gain $(p<0.01)$.

Table 3. Changes in the control and experimental groups urine output at different times of the experiment

\begin{tabular}{l|c|c|c|c|c|c|c|c}
\hline \hline & NPC & NPQ & NPE & NPQE & LPC & LPQ & LPE & LPQE \\
\hline $\begin{array}{l}\text { Pre-treatment 24 hours } \\
\text { urine volume (ml) }\end{array}$ & $17.3 \pm 4.1$ & $19.0 \pm 5.0$ & $19.2 \pm 5.0$ & $15.8 \pm 4.1$ & $10.6 \pm 3.2$ & $11.4 \pm 4.8$ & $13.4 \pm 5.1$ & $12.0 \pm 4.0$ \\
\hline $\begin{array}{l}\text { Mid-treatment 24 hours } \\
\text { urine volume (ml) }\end{array}$ & $20.0 \pm 5.1$ & $23.1 \pm 13$ & $21.4 \pm 4.0$ & $13.3 \pm 4.6$ & $11.5 \pm 8.8$ & $10.4 \pm 2.8^{*}$ & $5.9 \pm 3.1^{* *}$ & $6.4 \pm 3.4^{*}$ \\
\hline $\begin{array}{l}\text { Terminal urine } \\
\text { volume (ml) }\end{array}$ & $22.4 \pm 6.0$ & $23.4 \pm 9.4$ & $21.1 \pm 4.5$ & $14.6 \pm 4.0$ & $9.7 \pm 4.8^{*}$ & $12.8 \pm 3.0^{\beta}$ & $5.0 \pm 2.2^{* *}$ & $4.5 \pm 2.4^{* *}$ \\
\hline \hline
\end{tabular}

Asterisks * indicates significant difference $(P<0.01)$ compared to control (NPC), while ** indicate significant difference $(p<0.01)$ compared to NPC and respective cohorts (i.e. NP vs LP dietary groups). Pilcrow indicates significant difference in urine volume compared to baseline volume $(p<0.01)$ while beta $\beta$ indicates significant difference compared to mid-treatment volume $(p<0.01)$.

\section{Urine volume}

The urinary output results, as summarized in Table 3, showed significant changes in the measured volume at different times throughout the study (Two-way repeated-measures ANOVA, $p<0.0001$, $\mathrm{DF}=14, \mathrm{~F}=3.875)$. Mean pairwise comparison showed no significant difference between all the groups at the baseline measurement. At the midtreatment, LPQ ( $p=0.0209), \operatorname{LPE}(p=0.0008)$ and LPQE ( $p=0.0012)$ were significantly decreased compared to NPC. Also, only LPE $(p<0.0001)$ was significantly decreased compared to NPE. At the terminal measurement, LPC ( $p=0.0106)$, LPE ( $p=0.0009)$, LPQE ( $p=0.0006)$ were significantly decreased compared to NPC, while LPQ showed no significant difference. Furthermore, only LPE $(p<0.0001)$ and LPQE ( $p=0.0016)$ showed a significant difference compared to NPE and NPQE, respectively.

While comparing the volume changes be- tween the periods, the LPE subgroup showed a significant decrease between the baseline volume and mid-treatment volume $(p=0.0223)$ and between baseline volume and terminal volume $(p=0.0023)$. Furthermore, the LPQE subgroup showed a significant decrease between baseline volume and midtreatment volume $(p=0.0205)$ and between baseline volume and terminal volume $(p=0.0017)$. Lastly, LPQ showed a significant increase between midtreatment volume and terminal volume $(p=0.0311)$, while all remaining comparisons were not significant.

\section{Kidney weight}

Table 4 summarizes the results of kidney in absolute and relative measurements. Absolute kidney weight showed a significant decrease in the LP group compared to NPC and their respective cohorts (one-way ANOVA, $\mathrm{p}<0.0001, \mathrm{DF}=7, \mathrm{~F}=22.69$ ). 
Table 4. Kidney weight in rats administered chloroquine and/or ethanol while on normal or low protein diet

\begin{tabular}{l|c|c|c|c|c|c|c|c}
\hline \hline & NPC & NPQ & NPE & NPQE & LPC & LPQ & LPE & LPQE \\
\hline $\begin{array}{l}\text { Absolute kidney } \\
\text { weight }(\mathrm{g})\end{array}$ & $3.4 \pm 0.34$ & $3.5 \pm 0.36$ & $3.6 \pm 0.60$ & $3.5 \pm 0.25$ & $2.4 \pm 0.20^{*} 2.4 \pm 0.23^{* *}$ & $2.3 \pm 0.17^{* *}$ & $2.5 \pm 0.37^{* *}$ \\
\hline $\begin{array}{l}\text { RKW } \\
(\% \text { bodyweight })\end{array}$ & $0.61 \pm 0.04$ & $0.61 \pm 0.04$ & $0.60 \pm 0.04$ & $0.62 \pm 0.04$ & $0.57 \pm 0.03$ & $0.56 \pm 0.04$ & $0.55 \pm 0.05$ & $0.60 \pm 0.07$ \\
\hline
\end{tabular}

RKW - relative kidney weight.

Asterisks * indicates significant difference $(P<0.01)$ compared to control (NPC) while ${ }^{* *}$ indicate significant difference $(p<$ 0.01) compared to NPC and respective cohorts (i.e. NP vs LP dietary groups)

Relative kidney weight also showed a statistically significant difference (one-way ANOVA, $\mathrm{p}=0.0233$, $\mathrm{DF}=7, \mathrm{~F}=2.557)$.

\section{Kidney volume}

Kidney volume was significantly (one-way ANOVA, $\mathrm{p}<0.0001, \mathrm{DF}=7, \mathrm{~F}=9.377$ ) lower in LP groups compared to NPC and compared to their cohorts in NP, but no significance was recorded within the LP or within the NP (Figure 1).

\section{Glomeruli count}

Figure 2 shows the results of glomeruli count in a single camera field $\left(5.78 \mathrm{~mm}^{2}\right.$ area), with no statistically significant difference (one-way ANOVA, $\mathrm{p}$ $=0.0740, \mathrm{DF}=7, \mathrm{~F}=2.087$ ).

\section{Collagen fiber evaluation}

The Masson's trichrome stain qualitatively allows appreciation of the increased collagen fiber deposition in all the LP-treated groups compared to the NPC and their NP cohorts (Figure 3). Quantitatively, the amount of collagen fiber deposited was not significantly different between and within the groups (Kruskal-Wallis, $\mathrm{p}=0.1919$ ). (Figure 4).

\section{Histological changes}

The histological evaluation of the treatment is shown in Figure 5. The proximal tubule (Pt) shows normal low columnar cells with apical brush border intact (white arrow points at Pt cell nucleus), while the distal tubule (Dt) shows normal cuboidal cells with a paler cytoplasm (black arrow points at Dt cell nucleus) in the control groups (NPC, LPC). However, the renal corpuscle shows an intact glomerular tuft (Gl, Insert) surrounded with clearly visible urinary space (red arrowhead) in the NPC, but a narrowing of the same in the LPC.

All the treatment groups showed degeneration of the apical brush border $(\mathrm{Bb})$ in the proximal tubule $(\mathrm{Pt})$, except the NPE. However, degeneration of the distal tubule (Dt) cells and widening of its lumen is seen in all the treated groups. Besides, the proximal tubule showed vacuolation (blue arrow, in NPQ), necrosis (blue asterisk, in NPQ and LPE) and luminal debris (black arrowhead, in LPQ and LPQE).

In the glomeruli, narrowing of the urinary space (red arrowhead) is common to all the treatment groups.

\section{Aquaporin 2 (AQP2) water channel fluorescence evaluation}

The fluorescence intensity is highest in the LPQE, LPE and NPQE than NPC, while LPQ has the lowest intensity compared to NPC. Also, LPC, NPQ and NPE show no qualitative difference in the fluorescence intensity compared to NPC (Figure 6). In this regard, the high fluorescence intensity in the apical membrane indicates the upregulation of the AQP2 water channels. It signifies increased water reabsorption, while low fluorescence intensity indicates downregulation and reduced water reabsorption. Increased water reabsorption causes concentrated urine and a small urine output volume, whereas reduced water reabsorption causes diluted urine and large urine output volume. 


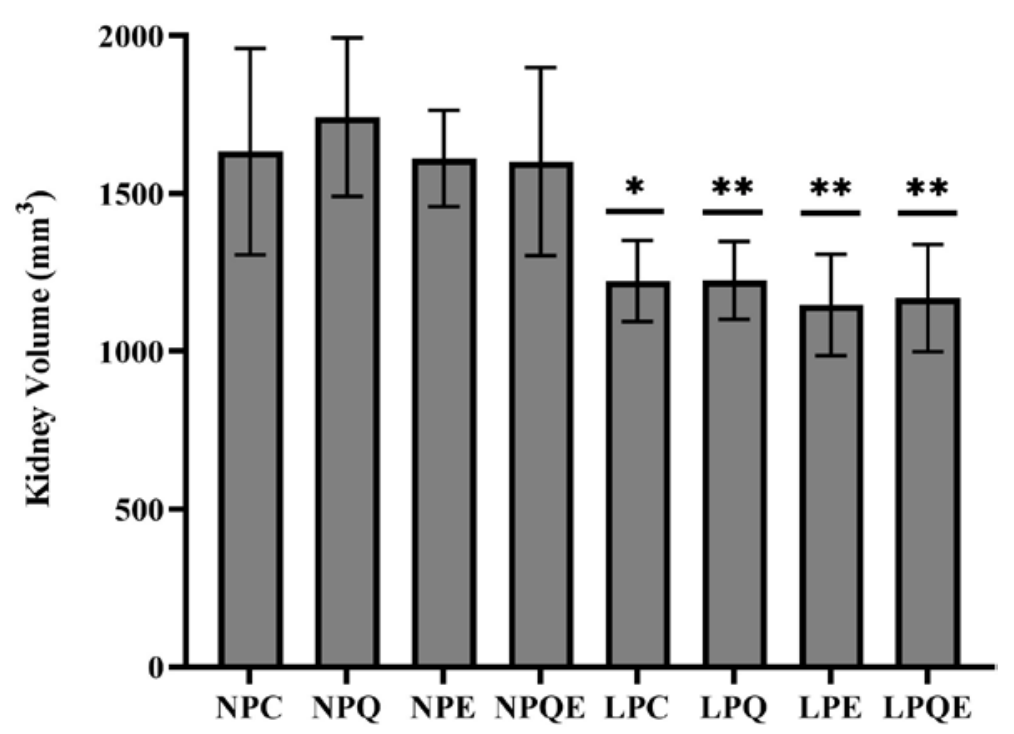

Figure 1. Effects of chloroquine and/or ethanol treatment on kidney volume in rats fed normal or low protein diet

Asterisks * indicates significant difference $(P<0.01)$ compared to control (NPC) while ${ }^{* *}$ indicate significant difference $(p<$ 0.01) compared to NPC and respective cohorts (i.e. NP vs LP dietary groups).

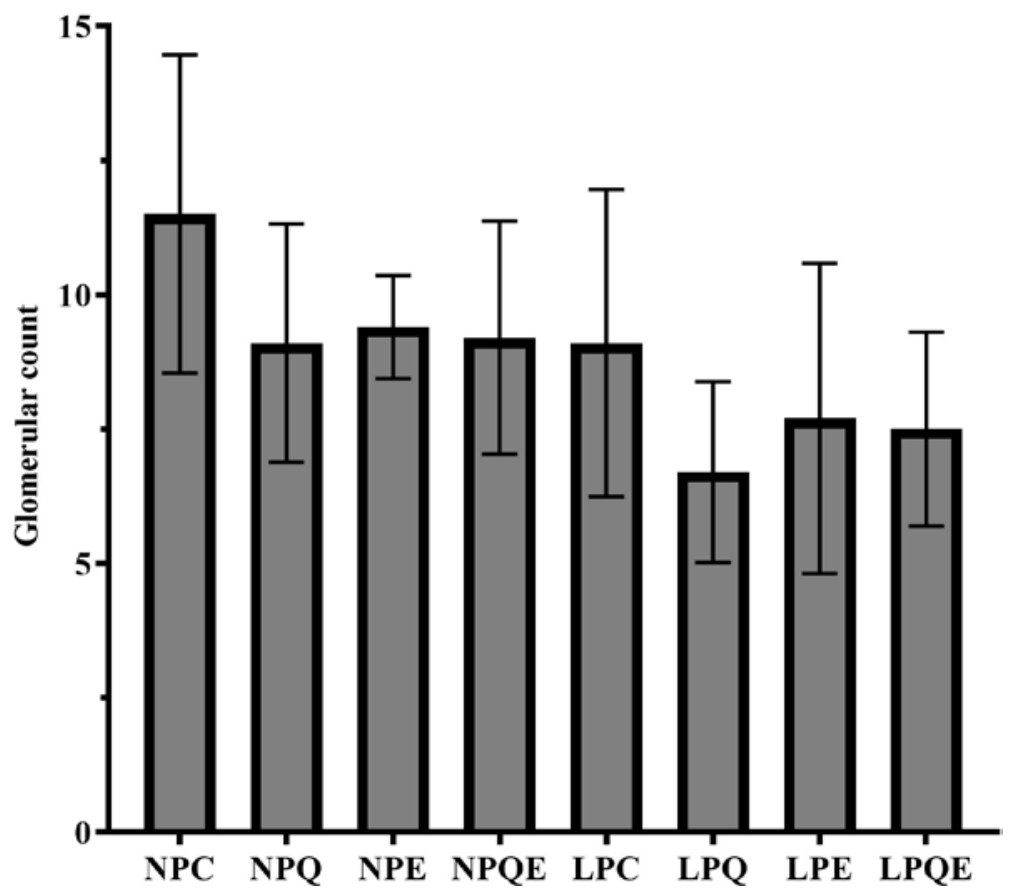

Figure 2. Renal glomeruli count following chloroquine and/or ethanol treatment in rats fed normal or low protein diet. No statistical difference was recorded. 

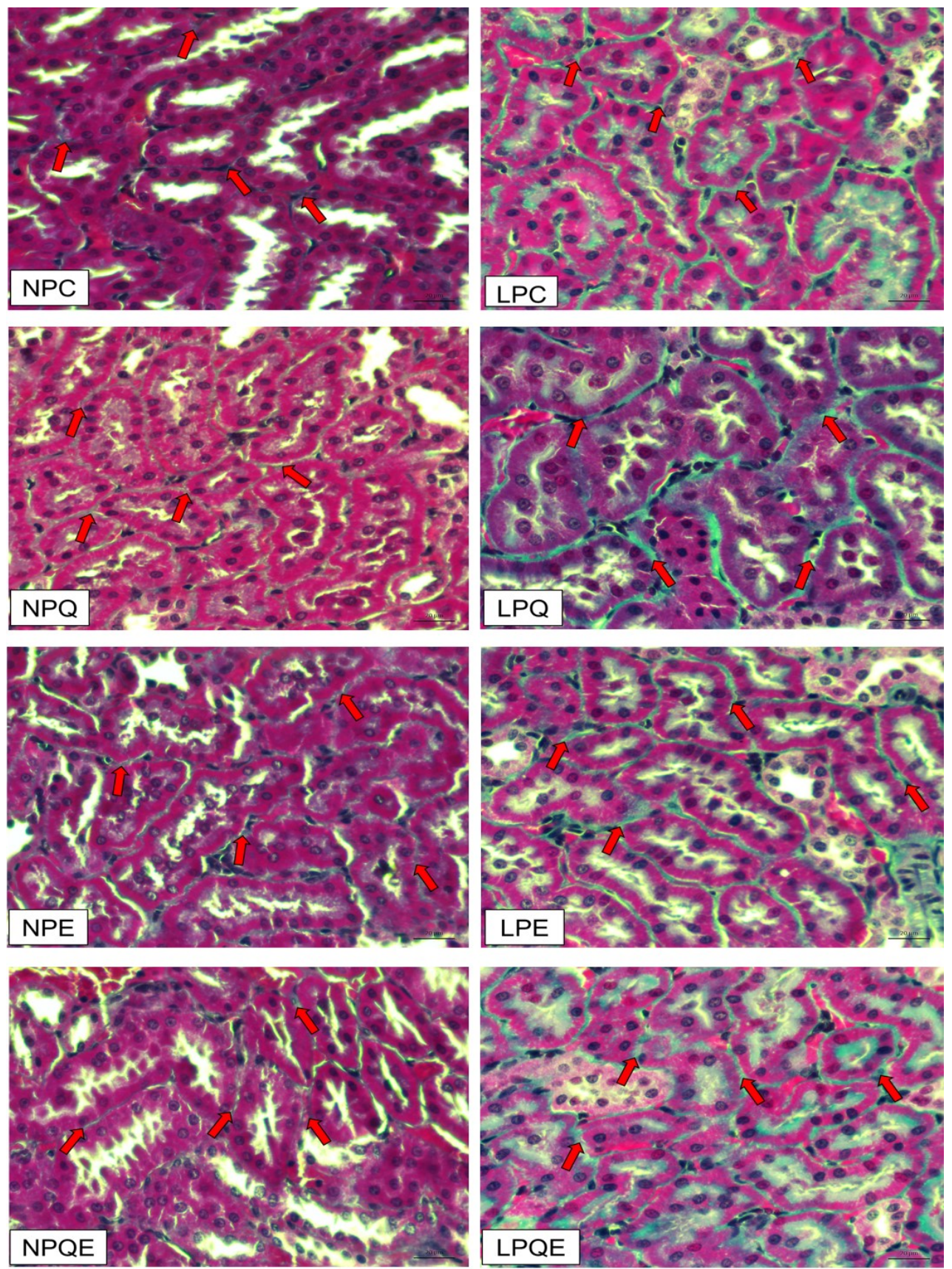

Figure 3. Histological sections of rat kidney showing collagen fiber demonstrated with Masson's trichrome stain (X63). Red arrows (in each treatment) indicates the collagen fibers and shows an increase in all the low protein treated compared to normal protein treated groups. 




Figure 4. Renal collagen fiber fraction in rats treated with chloroquine and/or ethanol and fed normal or low protein diet. No statistical difference was recorded. 

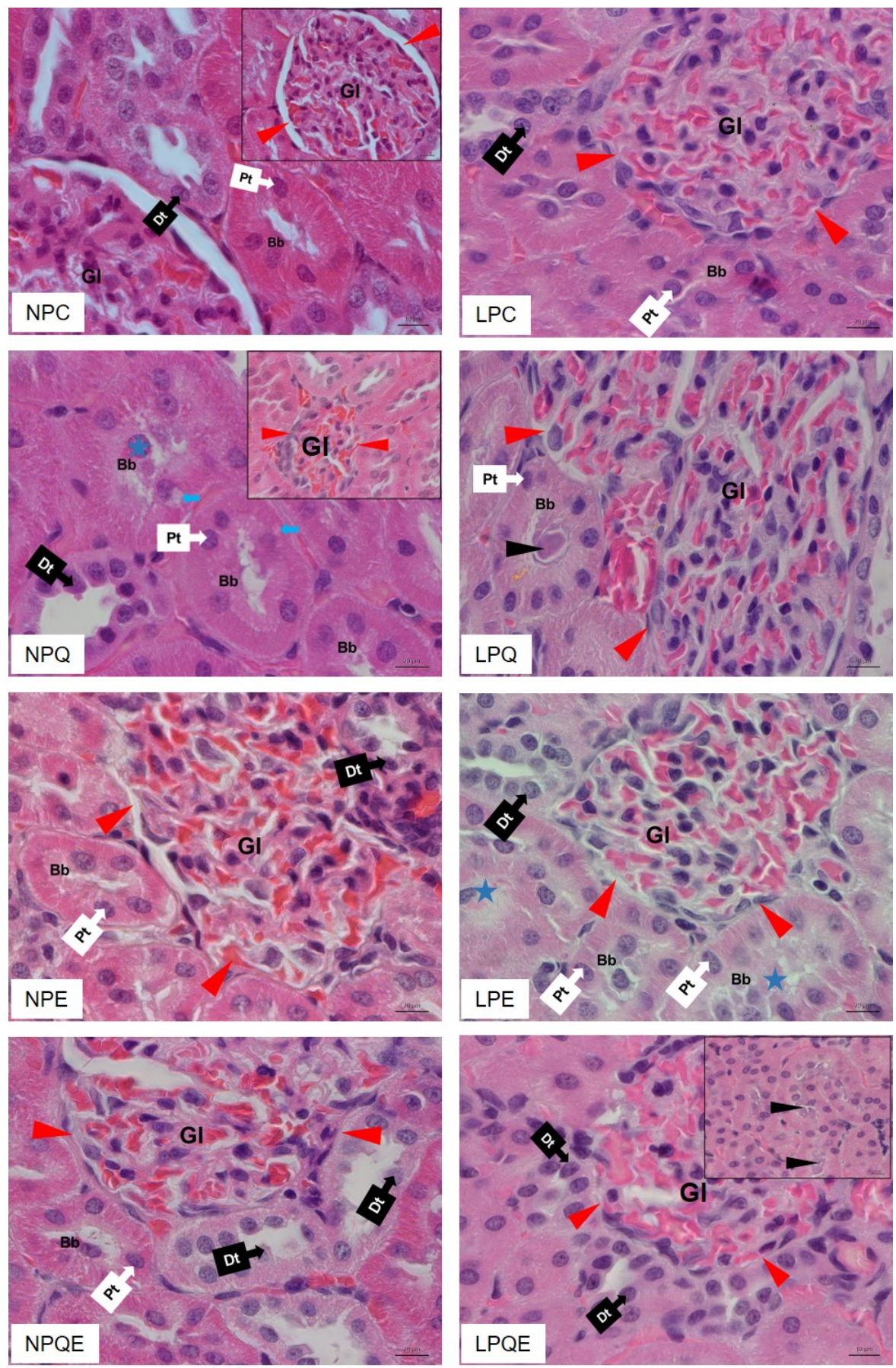

Figure 5. Representative histological images of light micrographs of kidney sections (X100) from the different treatment groups of rats. Blue asterisk shows necrosis; blue arrow shows vacuolation; red arrowhead shows the urinary space; black arrowhead shows debris.

$\mathrm{Pt}$ - proximal tubule, $\mathrm{Dt}$ - distal tubule, $\mathrm{Gl}$ - glomerulus, $\mathrm{Bb}$ - brush border. 

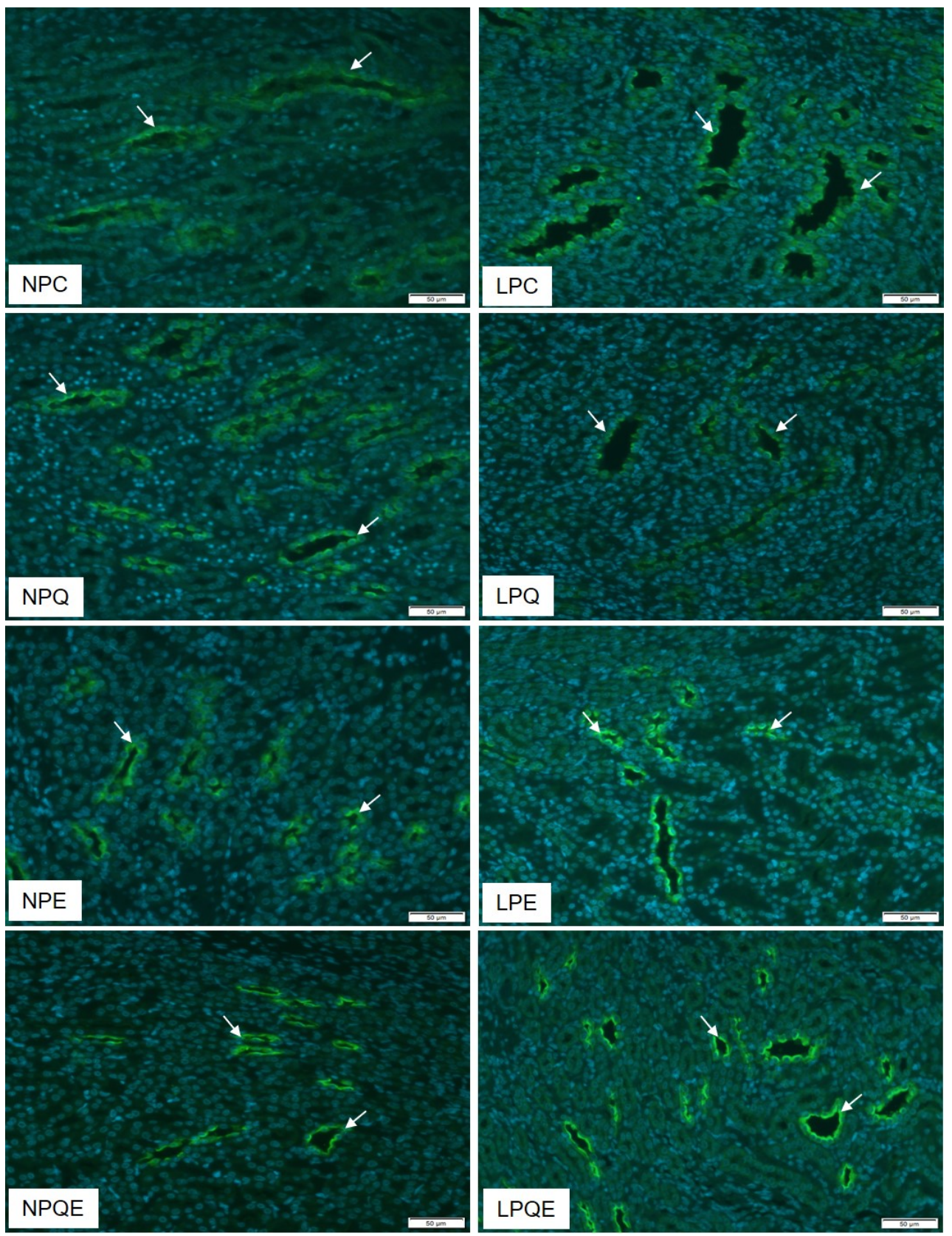

Figure 6: The AQP2 protein channels in kidney sections of the rats (fluorescence intensity; X20) treated with chloroquine and/or ethanol. White arrow indicates the apical membrane of the collecting duct where the protein channels are located.

\section{DISCUSSION}

The kidney is highly vulnerable to damage from an increased accumulation of excretion products in renal tubular cells during absorption and secretion. The results of this experiment suggested a high risk of renal morphological and histological distortions resulting from chloroquine and alcohol administration in a protein malnourished individual. This is common in rural sub-Saharan Africa, where carbohydrate is the principal diet with minimal access to quality dietary protein (10). Imbalanced dietary protein can lead to the accumulation of drug metabolic waste because of a reduction in the availability of enzymes responsible for its breakdown (11).

Although there was no death recorded throughout the experiment in all the groups, the low protein fed group's inability to gain significant weight is consistent with an earlier report (8). Body weight changes are vital for assessing health and 
disease status in an individual, being a critical indicator of a serious underlying health condition. Inadequate dietary protein is associated with many health problems, including skeletal muscle wasting and weight loss (10). However, despite the weight loss in the low protein groups, no significant changes in food consumption were recorded in all the experimental groups. This suggests that the weight loss in the low protein group is not associated with a lack of feeding but rather the relative protein intake (quality of the food), which may negatively affect the bodybuilding processes.

The organ weight in toxicity studies reveals invaluable insight, much like the microscopic changes. In this study, changes in kidney weight correlate with changes in body weight, especially considering that the duration of the study is not long to elicit a significant change in the weight. However, changes in kidney volume will further elucidate the actual morphological and histological changes.

Meanwhile, kidney volume assessment and comparisons showed significant kidney shrinkage in rats fed low protein. This may be accounted for by general body weight loss in addition to the kidney parenchymal contraction caused by increased collagen deposition (12). However, the absence of change in kidney volume in the ethanol-treated group contrasts with a previous report, which associated alcohol treatment with kidney swelling in humans and rats (13). Perhaps, it resulted from alcoholic liver cirrhosis linked with kidney enlargement in the study (13), which was not observed in this study possibly due to the duration of the experiment. Kidney volume is arguably the most significant clinical indicator of kidney disease progression (14).

Histological examination revealed that chloroquine and ethanol administration caused degeneration of the renal tubules and narrowing of the urinary space, as previously reported by Musabayane et al. (4). Additionally, combined treatments with chloroquine and ethanol also distorted Bowman's capsule and glomeruli tuft in normal and low protein groups. These changes indicate a cellular response to stress and injury, but the increased distortion in chloroquine treated group compared to ethanol treated group further suggests that chloroquine more adversely affected the renal morphology than ethanol in both dietary groups. The histological changes observed were associated with in- creased collagen deposition in low protein groups, indicating renal parenchymal damage.

Aquaporin 2 (AQP2) water channel regulation is instrumental to the urine concentrating mechanisms and the kidney function in regulating body water and electrolytes homeostasis. The AQP2 water channel helps further our understanding of the effects of chloroquine and ethanol in the absence or presence of protein malnutrition on normal renal fluid handling. Appropriate control of diet and water intake is essential for maintaining normal blood pressure, fluid and electrolyte homeostasis in the body (15). The results reveal that chloroquine modulates the downregulation of AQP2, as previously reported by lowering cAMP levels in the inner medulla (16) leading to increased urine output as recorded and perhaps with minimal effect on the body's electrolyte balance. However, alcohol is known to affect electrolyte balance in the body (17). Thus, the decreased urine output in the groups administered alcohol while on low protein diet may result from increased water reabsorption activated by AQP2 upregulation (increased apical AQP2 intensity) to maintain body fluid and electrolytes balance.

Furthermore, in groups with adequate protein, average urine output was maintained despite alcohol administration suggesting that protein imbalance played a significant role in the electrolyte derangements caused by alcohol administration.

Alcohol and chloroquine administration negatively impact kidney function, and the present results indicate that inadequate dietary protein might exacerbate the problem. However, these findings did not contrast the benefit of instituting a low protein diet regiment as part of the nutritional management of chronic kidney disease (18) since the present study was differently focused. The limitations of this study include perhaps failure to assess kidney function parameters as well as the short duration of the study. These areas will further our understanding of the renal functional derangement associated with chloroquine and alcohol administration in low protein diet condition.

\section{CONCLUSION}

This study's findings demonstrate the detrimental effect of chloroquine and ethanol administration in the kidney exacerbated by low protein dietary intake. This study also indicated that adequate die- 
tary protein might minimise renal distortions caused by ethanol and chloroquine.

\section{Acknowledgements}

The authors wish to acknowledge the Tertiary education trust fund (TETFUND) Nigeria for providing a study fellowship that made this study possible.

\section{References}

1. Krafts K, Hempelmann E, Skorska-Stania A. From methylene blue to chloroquine: a brief review of the development of an antimalarial therapy. Parasitol Res 2012;111(1):1-6. https://doi.org/10.1007/s00436-012-2886-x

2. Rainsford KD, Parke AL, Clifford-Rashotte M, et al. Therapy and pharmacological properties of hydroxychloroquine and chloroquine in treatment of systemic lupus erythematosus, rheumatoid arthritis and related diseases. Inflammopharmacol 2015;23(5):231-69. https://doi.org/10.1007/s10787-015-0239-y

3. Pisa P, Loots Du T, Nienaber C. Alcohol metabolism and health hazards associated with alcohol abuse in a South African context: a review. South Afr J Clin Nutr 2010;23(sup2):4-10. https://doi.org/10.1080/16070658.2010.11734295

4. Musabayane CT, Cooper RG, Osima E, et al. Renal electrolyte and fluid handling in the rat following chloroquine and/or ethanol administration. Gen Pharmacol-Vasc S 2000;34:43-51. https://doi.org/10.1016/S0306-3623(00)00045-8

5. Norman K, Stobaus N, Gonzalez MC, et al. Hand grip strength: outcome predictor and marker of nutritional status. Clin Nutr 2011;30(2):135-42. https://doi.org/10.1016/j.clnu.2010.09.010

6. Naicker S. End-stage renal disease in Sub-Saharan Africa. Kidney Int Suppl 2013;3(2):161-3. https://doi.org/10.1038/kisup.2013.4
7. Abdulkadir A, Mbajiorgu EF, Nyirenda T. Effects of concurrent chloroquine and ethanol administration on the rat kidney morphology. Pan Afr Med J 2018;29 https://doi.org/10.11604/pamj.2018.29.49.12471

8. Mbajiorgu EF, Aire TA, Volk W, et al. Low protein diet enhances the toxicity of combined ethanol and chloroquine administration on gonadal weight, seminiferous tubular diameter and epithelial height of male Sprague-Dawley rats: A morphometric study. Int J Health Sci 2008;1:120-6

9. Nogueira LC, do Rio RF, Lollo PCB, et al. Moderate Alcoholic Beer Consumption: The Effects on the Lipid Profile and Insulin Sensitivity of Adult Men. J Food Sci 2017;82(7):1720-5. https://doi.org/10.1111/1750-3841.13746

10. Wu G. Dietary protein intake and human health. Food Funct 2016;7(1251).

https://doi.org/10.1039/C5FO01530H

11. Hamberg O, Ovesen L, Dorfeldt A, et al. The effect of dietary energy and protein deficiency on drug metabolism. Eur J Clin Pharmacol 1990;38:567-70. https://doi.org/10.1007/BF00278583

12. Hewitson TD. Fibrosis in the kidney: is a problem shared a problem halved? Fibrogenesis Tissue Repair 2012;5:S14. https://doi.org/10.1186/1755-1536-5-S1-S14 
13. Epstein M. Alcohol's Impact on kidney function. Alcohol Res Health 1997;21(1):84-93.

14. Grantham JJ, Torres VE. The importance of total kidney volume in evaluating progression of polycystic kidney disease. Nat Rev Nephrol 2016;12(11):667-77.

https://doi.org/10.1038/nrneph.2016.135

15. Kim J-M, Kim T-H, Wang T. Effect of Diet and Water Intake on Aquaporin 2 Function. Child Kidney Dis 2016;20(1):11-7.

https://doi.org/10.3339/jkspn.2016.20.1.11

16. von Bergen TN, Blount MA. Chronic use of chloroquine disrupts the urine concentration mechanism by lowering cAMP levels in the inner medulla. Am J Physiol Renal Physiol 2012; 303 (6): F900-F905.

https://doi.org/10.1152/ajprenal.00547.2011

17. Palmer BF, Clegg DJ. Electrolyte disturbances in patients with chronic alcohol-use disorder. N Engl J Med 2017;377:1368-77.

https://doi.org/10.1056/NEJMra1704724

18. Bellizzi V, Cupisti A, Locatelli F, et al. Lowprotein diets for chronic kidney disease patients: the Italian experience. BMC Nephrol 2016;17(77):1-17.

https://doi.org/10.1186/s12882-016-0280-0 


\title{
Dugotrajna primena hlorokina i etanola izaziva ozbiljna morfološka oštećenja bubrega kod pacova na niskoproteinskom režimu ishrane
}

\author{
Abdurrahman Abdulkadir ${ }^{1,2}$, Ejikeme Felix Mbajiorgu ${ }^{1}$ \\ ${ }^{1}$ Katedra za histologiju i embriologiju, Odsek za anatomske nauke, Fakultet zdravstvenih nauka, \\ Univerzitet Witwatersrand, Johannesburg, Gauteng, Južna Afrika \\ ${ }^{2}$ Departman za anatomiju, Fakultet zdravstvenih nauka, Državni univerzitet Birnin Kebi, PMB 1157, \\ Država Kebi, Nigerija
}

S A ŽETAK

Cilj ove studije bilo je ispitivanje mikroskopskih bubrežnih promena kod pacova nakon istovremene primene hlorokina $i$ etanola, uz neadekvatan unosom proteina.

Šezdeset četiri pacova nasumično je podeljeno u osam grupa od po osam pacova: kontrolnu grupu sa normanlnim sadržajem proteina (NPC - eng.) ili na režimu ishrane sa niskim sadržajem proteina (LPC eng.); grupu tretiranu hlorokinom sa normalnim sadržajem proteina (NPQ - eng.) ili na niskoproteinskom režimu ishrane (LPQ - eng.); grupu tretiranu etanolom sa normalnim sadržajem proteina (NPE - eng.) ili sa niskim sadržajem proteina (LPE - eng.); grupe istovremeno tretirane hlorokinom $i$ etanolom sa normalnim sadržajem proteina (NPQE - eng.) ili sa niskim sadržajem proteina (LPQE). Hlorokin je u normalnom fiziološkom rastvoru administriran na nedeljnom nivou pacovima iz sledećih grupa: NPQ, LPQ, NPQE i LPQE, dok su pacovi iz grupa NPE, LPE, NPQE i LPQE primali šestoprocentni etanol kroz vodu za piće ad libitum. Pacovi grupa NPC i LPC primili su normalni fiziološki rastvor od $0,9 \%$ i običnu vodu za piće. Nakon tretmana, sprovedeno je rutinsko bojenje hematoksilinom i eozinom, Masonovo trihromno bojenje na kolagen, procenjivanje zapremine bubrega, određivanje broja glomerula, imunofluorescencija za akvaporin 2 i procena zapremine urina.

Rezultati su pokazali smanjeni volumen bubrega u svim eksperimentalnim grupama pacova u poređenju sa kontrolnom grupom. Kod pacova u eksperimentalnim grupama zabeleženo je povećano taloženje kolagenskih vlakana, kao i promena bubrežne histologije, u poređenju sa pacovima iz kontrolne grupe.

Istovremena primena hlorokina i alkohola dovodi do poremećaja histologije bubrega i bubrežne funkcije kod pacova hranjenim niskim sadržajem proteina, što može dovesti do bubrežne insuficijencije.

Ključne reči: hlorokin, etanol, nizak sadržaj proteina, VGStudio, akvaporin 2 